\title{
A Short Note on Translating Thomas Hardy's Biblical Allusions
}

\author{
Song Cho \\ Division of Language and Literature, Oklahoma Baptist University \\ Shawnee, OK 74804, USA
}

Received: 15-09- 2013

Accepted: 28-10- 2013

Published: 10-01- 2014

doi:10.7575/aiac.ijclts.v.2n.1p.34

URL: http://dx.doi.org/10.7575/aiac.ijclts.v.2n.1p.34

\section{Introduction}

In one of the many moving passages in Thomas Hardy's Tess of the D'Urbervilles, the heroine baptizes her dying child Sorrow. It is worth examining the following scene: "Her figure looked singularly tall and imposing as she stood in her long white nightgown, a thick cable of twisted dark hair hanging straight down her back to her waist. The kindly dimness of the weak candle abstracted from her form and features the little blemishes which sunlight might have revealed - the stubble scratches upon her wrists, and the weariness of her eyes - her high enthusiasm having a transfiguring effect upon the face which had been her undoing, showing it as a thing of immaculate beauty, with an impress of dignity which was almost regal. The little ones kneeling round, their sleepy eyes blinking and red, awaited her preparations full of a suspended wonder which their physical heaviness at that hour would not allow to become active" (my emphasis, 94).

\section{Translating the Baptism of Sorrow}

It is curious to note that the Spanish translation of this particular scene omits the word white when describing Tess's nightgown: "Tenía una figura imponente, y parecía más alta con su larga camisa de noche; un espeso ramal de negros cabellos trenzados colgábale por la espalda hasta la cintura" (123). ${ }^{1}$

At first consideration this may appear to be of negligible importance; after all, one can safely assume that nightgowns during this period were generally white for the most part. However, a close examination of Tess's description above suggests that Hardy may have borrowed the aforementioned italicized words, among others, from the Transfiguration passages of the New Testament of the King James Bible (Cho, 2012:66). Consider, for example, the following verse from the Gospel of Matthew: "And was transfigured before them: and his face did shine as the sun, and his raiment was white as the light" (my emphasis, 17:2). In this way, Hardy strongly associates Tess with the glorified figure of Christ through meticulously selected words. Hence, every word - including white - calls for attention. It is within this in mind, then, that one should approach the baptismal scene.

To be sure, there are other passages throughout the book that evoke the figure of Christ. Such a point becomes particularly significant when discussing the dispute generated by the novel's subtitle, namely A Pure Woman. In his preface to the MacMillan Wessex Edition (1912), Hardy writes: "Respecting the sub-title, to which allusion was made above, I may add that it was appended at the last moment, after reading the final proofs, as being the estimate left in a candid mind of the heroine's character - an estimate that nobody would be likely to dispute. It was disputed more than anything else in the book. Melius fuerat non scribere. But there it stands" (Appendix I). Furthermore, it is recorded in the author's autobiography that "the Duchess of Abercorn's dinner guests had been 'almost fighting across her dinnertable over Tess's character'. Those who thought the 'little harlot' deserved hanging were put in one group; those who pitied her as a 'poor wronged innocent' sat in another, together with the Duchess" (xix). ${ }^{2}$

\section{Conclusion}

All this inevitably leads us to ask: what about the other translations? It will be well to recall that there is a high concentration of biblical allusions contained in Hardy's novels - some are immediately apparent while others are not. This being so, it is incumbent upon the translator to identify the biblical allusions echoed throughout Hardy's literary production and translate them accordingly.

\section{References}

Cho, S.. (2012) “Tess of the D'Urbervilles and the Transfiguration of Christ." Hardy Society Journal 8, no. 2. 66. Hardy, T. (2003) Tess of the D'Urbervilles. Ed. Tim Dolin. New York: Penguin Books.

Hardy, T. and Ortega, M. (1999) Tess, la de los d'Urbervilles. Madrid: Alianza Editorial.

\section{Notes}

${ }^{1 .}$ It should be stated that this sentence remains unchanged in the latest edition (2013) of this book by Alianza Editorial.

2. The introduction is by Margaret R. Higonnet. Reference is made to Thomas Hardy, The Life and Work of Thomas Hardy, ed. Michael Millgate (London: Macmillan, 1985), p. 258. 